\title{
MELATIH KETERAMPILAN BERPIKIR KRITIS MELALUI FACEBOOK DALAM MATA KULIAH MULTIMEDIA PADA MAHASISWA FISIKA UNESA
}

\author{
Rudy Kustijono \\ Jurusan Fisika Universitas Negeri Surabaya \\ e-mail: rudyunesa@gmail.com
}

\begin{abstract}
Abstrak: Telah dilakukan penelitian pengembangan pembelajaran melalui facebook yang dapat melatihkan keterampilan berpikir kritis dalam mata kuliah multimedia. Penelitian tersebut dilakukan untuk mencari satu alternatif pembelajaran efektif yang menggunakan teknologi informasi dan komunikasi (TIK). Di samping itu adalah menjadi pendorong agar tren penggunaan facebook khususnya oleh kalangan pelajar dan mahasiswa dapat diberdayakan untuk penggunaan yang lebih bermanfaat. Jenis penelitian yang dilakukan adalah Penelitian dan Pengembangan atau Research and Development (R\&D), dengan langkah penelitian studi pendahuluan, pengembangan produk dan ujicoba produk. Pokok bahasan penelitian adalah materi yang berhubungan dengan fisika dan aplikasinya, sedangkan ujicoba terbatas diterapkan pada mahasiswa Jurusan Fisika Unesa yang berjumlah 50 orang yang sedang memprogram mata kuliah multimedia pada semester gasal tahun akademik 2012-2013. Berdasarkan hasil penelitian di atas dapat disimpulkan bahwa pembelajaran melalui facebook dapat digunakan untuk melatihkan keterampilan berpikir kritis mahasiswa berdasarkan penilaian dosen maupun mahasiswa yang memberikan penilaian baik (analyzing $\geq 80 \%$, synthesizing $\geq 70 \%$, evaluating $\geq 75 \%$, applying $\geq 90 \%$, generating ideas $\geq 85 \%$, expressing ideas $\geq 80 \%$, dan problems solving $\geq 62 \%$ ).
\end{abstract}

Kata kunci: TIK, facebook, keterampilan berpikir kritis.

\section{PENDAHULUAN}

Para peramal masa depan (futurist) mengatakan abad 21 sebagai abad pengetahuan. karena pengetahuan akan menjadi landasan utama segala aspek kehidupan (Trilling dan Hood, 1999). Pada tahun 2007, The National Academies menyelenggarakan lokakarya hasil penelitian yang terkait dengan keterampilan masa depan. Hasil lokakarya tersebut menyimpulkan bahwa setidaknya diperlukan lima keterampilan yang secara luas diperlukan di berbagai pekerjaan, yaitu: adaptability, complex communications/social skills, non-routine problem solving, self-management/self-development, dan systems thinking (Ruiz dan Primo, 2009). Untuk mengantisipasi abad 21, model pembelajaran yang diperlukan adalah yang memungkinkan terbudayakannya kecakapan berpikir ilmiah, terkembangkannya "sense of inquiry" dan kemampuan berpikir kreatif siswa (De Vito, 1989).

Fisika adalah ilmu yang mempelajari gejala alam yang tidak hidup atau materi dalam lingkup ruang dan waktu. Para fisikawan atau ahli fisika mempelajari perilaku dan sifat materi dalam bidang yang sangat beragam, mulai dari partikel submikroskopis yang membentuk segala materi (fisika partikel) hingga perilaku materi alam semesta sebagai satu kesatuan kosmos. Budaya penelitian fisika berbeda dengan ilmu lainnya karena adanya pemisahan teori dan eksperimen. Sejak abad kedua puluh, kebanyakan fisikawan mengkhususkan diri meneliti dalam fisika teoretis atau fisika eksperimental saja, dan sedikit saja yang berhasil dalam kedua bidang tersebut secara serempak. Teoris berusaha mengembangkan teori yang dapat menjelaskan hasil eksperimen yang telah dicoba dan dapat memperkirakan hasil eksperimen yang akan datang. Sementara itu, eksperimentalis menyusun dan melaksanakan eksperimen untuk menguji perkiraan teoretis.

Meskipun teori dan eksperimen dikembangkan secara terpisah, mereka saling bergantung. Kemajuan dalam fisika biasanya muncul ketika eksperimentalis membuat penemuan yang tak dapat dijelaskan dari teori yang ada, sehingga mengharuskan dirumuskannya teori- teori baru. Tanpa eksperimen, penelitian teoretis sering berjalan ke arah yang salah. (id.wikipedia.org).

Pada tahapan awal, semua mahasiswa jurusan fisika setidaknya harus menguasai fisika dasar. Feynman (2010) berpendapat bahwa fisika dasar adalah gagasan dasar yang timbul dari penerapan metode ilmiah yang menelaah gagasan yang paling mendasar tentang sifat- sifat fisika. Fisika dasar membahas konsep-konsep dan prinsip-prinsip dasar fisika yang diperlukan untuk belajar fisika lebih lanjut atau ilmu pengetahuan lainnya. Pembelajaran fisika mempelajari permasalahan yang berkaitan dengan fenomena alam dan berbagai permasalahan dalam kehidupan sehari-hari. Fenomena alam dapat ditinjau dari objek, persoalan, tema dan tempat kejadiannya. Pembelajaran fisika memerlukan kegiatan penyelidikan baik melalui observasi maupun eksperimen, sebagai bagian dari kerja ilmiah yang melibatkan keterampilan proses yang 
dilandasi sikap ilmiah. Selain itu pembelajaran fisika mengembangkan rasa ingin tahu melalui penemuan berdasarkan pengalaman langsung yang dilakukan melalui kerja ilmiah. Melalui kerja ilmiah, siswa dilatih untuk memanfaatkan fakta, membangun konsep, prinsip, teori sebagai dasar untuk berfikir analitis, kritis dan kreatif.

Dalam pembelajaran fisika, mahasiswa setidaknya dapat menguasai empat hal, yaitu :

1. menguasai konsep-konsep fisika,

2. terampil menggunakan keterampilan berpikir dan keterampilan motorik,

3. memiliki sikap-sikap positif sebagaimana yang dimiliki oleh para fisikawan,

4. mampu menerapkan konsep-konsep fisika dan mempunyai keterampilan berpikir untuk memecahkan masalah sehari-hari.

Berdasarkan penjelasan di atas, keterampilan yang juga dikembangkan dalam melakukan penyelidikan fisika adalah keterampilan berpikir kritis (critical thinking skills). Berpikir kritis adalah cara berpikir tentang subjek apapun, isi, atau masalah di mana pemikir meningkatkan kualitas berpikirnya dengan terampil dalam menganalisis, menilai, dan merekonstruksi. Berpikir kritis itu mengarahkan diri (self-directed), disiplin diri (self- diciplined), terpantau (self-monitored), dan korektif (self- corrective). Berpikir kritis merupakan proses intelektualitas yang disiplin tentang keaktifan dan keterampilan konseptualisasi, penerapan, analisis, sintesis, dan/atau mengevaluasi informasi yang diperoleh dari, atau dihasilkan oleh, pengamatan, pengalaman, refleksi, penalaran, atau komunikasi, sebagai panduan untuk mempercayai dan melakukan. Berpikir kritis didasarkan pada nilai-nilai intelektual universal yang melampaui bagian materi subjek: kejelasan, ketepatan, presisi, konsistensi, relevansi, bukti, alasan-alasan, kedalaman materi, keluasan, dan keadilan. Berpikir kritis memerlukan komunikasi yang efektif dan kemampuan pemecahan masalah, serta komitmen untuk mengatasi egocentrism dan sociocentrism. Keterampilanketerampilan yang dikembangkan dalam berpikir kritis adalah seperti tabel 1 berikut (Valentino, 2000):

Tabel 1. Keterampilan-keterampilan berpikir kritis

\begin{tabular}{|c|l|l|}
\hline No. & Keterampila & \multicolumn{1}{|c|}{ Deskripsi } \\
\hline 1 & $\begin{array}{l}\text { Menganalisis } \\
\text { (Analyzing) }\end{array}$ & $\begin{array}{l}\text { Mempelajari sesuatu untuk } \\
\text { mengidentifikasi unsur-unsur } \\
\text { atau hubungan antar unsur- } \\
\text { unsur }\end{array}$ \\
\hline 2 & $\begin{array}{l}\text { Mensitesis } \\
\text { (Synthesizing) }\end{array}$ & $\begin{array}{l}\text { Menggunakan penalaran } \\
\text { deduktif untuk menarik } \\
\text { serentak unsur-unsur kunci }\end{array}$ \\
\hline 3 & $\begin{array}{l}\text { Menilai } \\
\text { (Evaluating) }\end{array}$ & $\begin{array}{l}\text { Meninjau dan menanggapi } \\
\text { secara } \\
\text { kritis bahan, prosedur, atau } \\
\text { gagasan, dan menilai mereka } \\
\text { dengan tujuan, standar, atau } \\
\text { kriteria lainnya }\end{array}$ \\
\hline
\end{tabular}

\begin{tabular}{|c|l|l|}
\hline 4 & $\begin{array}{l}\text { Menerapkan } \\
\text { (Applying) }\end{array}$ & $\begin{array}{l}\text { Menggunakan gagasan- } \\
\text { gagasan, } \\
\text { proses, atau keterampilan } \\
\text { dalam situasi baru }\end{array}$ \\
\hline 5 & $\begin{array}{l}\text { Membangkitkan } \\
\text { Gagasan } \\
\text { (Generating } \\
\text { Ideas) }\end{array}$ & $\begin{array}{l}\text { Mengekspresikan pikiran } \\
\text { yang } \\
\text { mengungkapkan orisinalitas, } \\
\text { spekulasi, imajinasi, sebuah } \\
\text { perspektif pribadi, } \\
\text { fleksibilitas dalam berpikir, } \\
\text { penemuan atau kreativitas. }\end{array}$ \\
\hline 6 & $\begin{array}{l}\text { Mengekspresikan } \\
\text { Gagasan } \\
\text { (Expressing } \\
\text { Ideas })\end{array}$ & $\begin{array}{l}\text { Menyajikan gagasan awal } \\
\text { dan logis sambil } \\
\text { menggunakan bahasa yang } \\
\text { sesuai bagi audien }\end{array}$ \\
\hline 7 & $\begin{array}{l}\text { Memecahkan } \\
\text { masalah } \\
\text { (Problems } \\
\text { solving) }\end{array}$ & $\begin{array}{l}\text { Menggunakan keterampilan } \\
\text { berpikir kritis untuk } \\
\text { menemukan pemecahan } \\
\text { masalah }\end{array}$ \\
\hline 1 & $\begin{array}{l}\text { Menganalisis } \\
\text { (Analyzing) }\end{array}$ & $\begin{array}{l}\text { Mempelajari sesuatu untuk } \\
\text { mengidentifikasi unsur-unsur } \\
\text { atau hubungan antar unsur- } \\
\text { unsur }\end{array}$ \\
\hline
\end{tabular}

Berpikir kritis melibatkan berpikir dan bernalar logis yang mencakup keterampilan seperti membandingkan, mengklasifikasi, mengurutkan, sebab-akibat, mempolakan, membuat jaringan (webbing), analogi, penalaran deduktif dan induktif, meramal, merencanakan, membuat hipotesis, dan mengkritik. Kemampuan berpikir mahasiswa untuk membandingkan dua atau lebih informasi, misalkan informasi yang diterima dari luar dengan informasi yang dimiliki. Bila terdapat perbedaan atau persamaan, maka ia akan mengajukan pertanyaan atau komentar dengan tujuan untuk mendapatkan penjelasan.

Seperti kita ketahui bersama bahwa perkembangan TIK (Teknologi Informasi dan Komunikasi) yang sangat pesat membawa perubahan besar pada segala bidang termasuk bidang pendidikan. Hartono (2004) mengemukakan bahwa pemanfaatan TIK untuk meningkatkan mutu pendidikan dapat dilakukan dengan berbagai cara, salah satunya adalah dalam pembelajaran. Proses pembelajaran dengan memanfaatkan TIK diyakini akan mempermudah pemahaman materi pelajaran. Perkembangan TIK yang sangat pesat membawa konsekuensi tentang pentingnya penyediaan sumber daya manusia (SDM) yang mampu memanfaatkan teknologi tersebut. Pendidikan masa depan dituntut harus mampu melibatkan teknologi secara terpadu dalam pembelajaran. Untuk memenuhi kebutuhan tersebut, Jurusan Fisika Unesa mencantumkan mata kuliah "Multimedia" yaitu mata kuliah yang melatih mahasiswa agar mampu mengapresiasi hasil karya berbasis multimedia pembelajaran, mampu menerapkan multimedia dalam media pembelajaran presentasi, mampu mengembangkan media video pembelajaran, mampu mengembangkan website dan webblog, dan mampu mengembangkan media pembelajaran 
animasi. Bagaimanapun sebagai mahasiswa fisika, yang bersangkutan harus mengusai materi fisika agar tidak terjadi kesalahan konsep pada multimedia yang dibuatnya. Untuk itu, dalam mata kuliah multimedia mahasiswa perlu dilatih pula keterampilan berpikir kritis tentang fisika dan aplikasinya dalam kehidupan sehari-hari.

Saat ini kita tidak akan asing dengan situs jejaring sosial yang bernama facebook. Situs jejaring sosial yang dibuat Mark Zuckerberg ini telah mewabah jutaan manusia di seluruh dunia. Banyak sekali manfaat dan kelebihan yang dimiliki facebook jika dibandingkan dengan situs jejaring sosial lain disamping kelemahannya. Salah satu kelebihan yang dimiliki facebook adalah dapat digunakan untuk membangun komunitas. Dengan komunitas tersebut, kita dapat sharing dan mencari solusi pemecahan tentang berbagai persoalan dengan sesama anggota komunitas. Sayangnya, jika kita amati penggunaan facebook oleh pelajar/mahasiswa di tanah air (kompasiana.com), fasilitas facebook justeru kerap digunakan untuk sesuatu yang tidak bermanfaat atau hanya sekedar untuk bersenang-senang (just for fun) belaka. Suatu keputusan yang sangat tidak tepat jika kita menyalahkan facebook, karena pada dasarnya teknologi itu bersifat netral. Oleh karena itu, kita perlu mengajak para pelajar/mahasiswa memanfaatkan facebook ini dengan cara yang lebih positif. Hasil penelitian menunjukkan bahwa pembelajaran melalui facebook dapat digunakan untuk melatihkan keterampilan proses sains dasar (Kustijono, 2012).

Proses belajar mengajar hakikatnya adalah proses komunikasi, dosen berperan sebagai pengantar pesan dan mahasiswa sebagai penerima pesan. Pesan yang dikirimkan oleh dosen berupa materi yang dituangkan ke dalam simbol-simbol komunikasi baik verbal (kata-kata dan tulisan) maupun nonverbal. Proses ini dinamakan encoding. Penafsiran simbol-simbol komunikasi tersebut oleh mahasiswa dinamakan decoding. Media adalah segala sesuatu yang dapat digunakan untuk menyalurkan pesan dari pengirim pesan ke penerima sehingga dapat merangsang fikiran, perasaan, perhatian, minat, dan perhatian siswa sedemikian rupa sehingga proses belajar mengajar terjadi (Sadiman, 2007). Media pembelajaran adalah bahan, alat atau teknik yang digunakan dalam kegiatan belajar mengajar dengan maksud agar proses interaksi komunikasi edukasi antara dosen dan mahasiswa dapat berlangsung secara tepat guna dan berdaya guna.

Dengan media pembelajaran yang tepat, mahasiswa diharapkan mampu menangkap seluruh materi yang disampaikan secara jelas dan mahasiswa dapat benar-benar memahami materi yang disampaikan. Ketepatan dalam pemilihan media pembelajaran juga akan menambah keefektifan proses pembelajaran, karena pemilihan media pembelajaran yang menarik dapat menimbulkan rasa ingin tahu yang tinggi mahasiswa dan hal ini akan mempermudah terjadinya proses pembelajaran itu sendiri. Media pembelajaran yang menarik juga dapat menjadikan mahasiswa lebih aktif dalam proses pembelajaran. Media pembelajaran juga dapat digunakan untuk menjalin komunikasi antara dosen dan mahasiswa.

Facebook adalah jejaring sosial yang perkembangannya sangat pesat di kalangan remaja dewasa ini. Facebook menduduki rangking pertama sebagai jejaring sosial yang terlaris diantara jejaring- jejaring sosial lainnya. Pengguna facebook di Indonesia mulai dari kalangan anak hingga dewasa. Tetapi sebagian besar pengguna facebook adalah kalangan remaja. Begitu banyak kalangan remaja yang sudah menggunakan jejaring sosial yang satu ini. Kemudahan yang didapatkan di facebook adalah daya tarik tersendiri bagi para remaja. Hampir sebagian besar bahkan mungkin semua remaja di Indonesia memiliki akun facebook.

Penggunaan facebook sebagai media pembelajaran, terdapat kelebihan dan kekurangan. Di era globalisasi, penggunaan facebook sebagai media pembelajaran menjadi sangat efektif, karena mahasiswa akan tertarik dengan penggunaan teknologi-teknologi yang sedang berkembang saat ini. Karena facebook saat ini menjadi jejaring sosial yang sangat digandrungi para remaja, mahasiswa akan sangat tertarik dengan materi yang disampaikan lewat facebook. Di samping itu, karena para mahasiswa sudah memiliki akun facebook dan sangat aktif dalam menggunakannya, maka akan memperlancar proses pembelajaran yang menggunakan facebook tersebut.

Namun dibalik kelebihan yang dimiliki, facebook juga memiliki kelemahan, salah satunya adalah penggunaannya tidak dapat dikontrol. Mahasiswa yang terlalu asyik menggunakan facebook dapat mengabaikan tugas yang seharusnya diselesaikan dan malah asyik menggunakan facebook untuk hal-hal yang tidak penting seperti mengupdate status, mengomentasi status orang lain, chatting dengan orang lain di luar konteks materi. dll. Di samping itu, kekurangan facebook adalah dapat membuat kita malas dengan tugas-tugas yang seharusnya dikerjakan, karena facebook memiliki aplikasi-aplikasi yang sangat menarik. Facebook juga dapat menyebabkan kurangnya sosialisasi dengan masyarakat. Hal ini yang membuat orang-orang di era globalisasi sekarang ini lebih bersifat individual. Pemikiran mereka juga terkadang terlalu kritis tanpa melihat bagaimana keadaan sosial orang lain. Dan dengan demikian akan menimbulkan kesenjangan sosial di masyarakat.

Facebook sebagai salah satu sarana yang ada di internet mempunyai berbagai macam aplikasi yang dapat kita jadikan sebagai media pembelajaran. Selama ini 
facebook lebih banyak dipakai untuk sekedar bersenangsenang, bersilaturrahim dengan teman, atau sekedar ajang narsis-narsisan. Sampai saat ini, banyak pihak yang memandang facebook secara negatif. Mereka berpikir bahwa keberadaan facebook dapat menurunkan kinerja pegawai. Ada juga yang mengatakan facebook itu berbahaya karena dapat digunakan sebagai sarana pelecehan dan pencemaran nama baik dengan maraknya group-group "say-no-to". Diluar sisi negatif itu, facebook tetap memiliki banyak manfaat, jauh lebih banyak dari pada mudharat-nya. Efek negatif itu muncul hanya karena oknum-oknum tertentu yang tidak menggunakan teknologi sebagaimana mestinya. Fitur- fitur dalam facebook yang dapat dipergunakan untuk pembelajaran paling tidak ada 9 yaitu: Share, Quiz, Note, Apps, Up Date Status, Forum, Up Load Photo, Pesan, Chatting. Masingmasing fitur dalam facebook tersebut dapat dijelaskan sbb:

1. Facebook Share: Fitur ini dapat digunakan sebagai sarana untuk membantu pembelajaran. Siapapun dapat men-share apapun (tulisan singkat, link, gambar, video dsb) ke semua teman-temannya. Dengan fitur tersebut dosen dapat mencari situs-situs atau gambar-gambar yang berhubungan dengan pembelajaran, kemudian di share di facebook untuk seterusnya dapat diakses oleh mahasiswa, sehingga mahasiswa mempunyai panduan dalam mencari materi di internet, dengan share ini dosen dapat menugasi mahasiswa untuk memberikan analisis, kritik atau komentar terhadap fenomena yang berada di dalam share/tautan tersebut.

2. Facebook Quiz: Fitur ini menyediakan quiz-quiz yang beredar di facebook. Rata-rata hanya quiz yang dibuat untuk sekedar iseng. Fitur ini sebenarnya dapat dipakai untuk melakukan quiz online. Dosen dapat membuat quiz kemudian memerintahkan mahasiswa untuk mengerjakan quiz tersebut. Dosen juga dapat mengganti tugas yang berupa pertanyaan dengan membuat quiz ini, di dalam quiz ini dosen juga dapat menetapkan skor yang diperoleh mahasiswa berdasarkan jawaban yang mereka berikan.

3. Facebook Note. Fitur ini dapat digunakan sebagai sarana dosen untuk memancing mahasiswa agar saling berdiskusi mengenai topik tertentu. Dosen membuat note di-wall kemudian men-tag ke seluruh mahasiswa untuk memancing diskusi.

4. Facebook Apps: Dengan fitur ini hampir segalanya dapat dilakukan. Salah satunya adalah dengan membuat sebuah game edutainment pada platform facebook Apps ini. Salah satu contoh Facebook Apps game edutainment yang cukup terkenal dan banyak dimainkan adalah Geo Challenge. Sebuah aplikasi game untuk menguji pengetahuan geografis dari pemain-pemainnya.
5. Up Date Status: Melalui fitur ini, Dosen dapat mengingatkan mahasiswa tentang materi yang akan dipelajari dalam pertemuan selanjutnya, memberi stimulus, atau memberi jalan sebagai ajang diskusi melalui "komentari", sehingga mahasiswa dipancing untuk berdiskusi.

6. Forum: Fitur ini dapat dijadikan sarana diskusi antara mahasiswa dengan dosen maupun antara mahasiswa dengan mahasiswa.

7. Up Load Photo: Dengan fitur ini dosen maupun mahasiswa dapat meng-up load foto/gambar yang berhubungan dengan materi, kemudian foto tersebut dapat di share dan dijadikan tema diskusi dengan sarana "komentari"

8. Pesan: Melalui layanan pesan, dosen dapat memberikan tugas atau rekomendasi sumber yang dapat mahasiswa akses di internet.

9. Chating: Dengan ada layanan ini, dosen dan mahasiswa dapat memanfaatkannya untuk sarana tanya jawab ataupun diskusi mahasiswa dalam mengerjakan suatu tugas dari dosen walaupun mahasiswa tersebut berada di tempat yang berbeda.

Memperhatikan karakteristik pembelajaran yang melatihkan keterampilan berpikir kritis dan karakteristik facebook seperti diuraikan di atas, penulis memandang, facebook dapat digunakan untuk mendukung proses pembelajaran di sekolah atau di kampus yang hasilnya diyakini cukup efektif. Oleh karena itu diperlukan penelitian untuk mengembangkan pembelajaran melalui facebook yang dapat melatihkan keterampilan berpikir kritis mahasiswa. Pertanyaan penelitian yang dapat dikemukakan adalah:

1. Bagaimanakah pembelajaran melalui facebook yang dapat melatihkan keterampilan berpikir kritis pada mahasiswa fisika pemrogram mata kuliah multimedia?

2. Bagaimanakah dampak pembelajaran melalui facebook terhadap keterampilan berpikir kritis mahasiswa?

Hasil pengembangan tersebut diharapkan dapat menjadi satu alternatif pembelajaran efektif yang menggunakan teknologi informasi dan komunikasi (TIK). Di samping itu juga dapat digunakan sebagai pendorong agar tren penggunaan facebook khususnya oleh kalangan pelajar dan mahasiswa dapat diberdayakan untuk penggunaan yang lebih bermanfaat. Bagi proses pembelajaran dalam mata kuliah "multimedia" sendiri, diharapkan dapat menjadi PAIKEM yaitu pembelajaran yang aktif, inovatif, kreatif, efektif, dan menyenangkan.

\section{METODE PENELITIAN}

Penelitian yang dilakukan termasuk dalam jenis Penelitian dan Pengembangan atau lebih dikenal dengan Research and Development (R\&D) yaitu suatu proses atau 
langkah untuk mengembangkan suatu produk baru atau menyempurnakan produk yang telah ada, yang dapat dipertanggungjawabkan. Produk tersebut tidak selalu berbentuk benda atau perangkat keras (hardware), seperti buku, modul, alat bantu pembelajaran di kelas atau laboratorium, tetapi bisa juga perangkat lunak (software), seperti program komputer pengolah data, ataupun modelmodel pendidikan, pembelajaran, pelatihan, bimbingan, evaluasi, manajemen (Sukmadinata, 2012). Langkah penelitian yang dilakukan secara garis besar adalah:

1. Studi pendahuluan yang meliputi studi literatur, studi lapangan, dan penyusunan draf awal produk.

2. Pengembangan produk yang terdiri dari melakukan ujicoba terbatas dan melakukan ujicoba luas,

3. Ujicoba produk melalui eksperimen dan sosialisasi produk

Karena keterbatasan penulis, penelitian yang dilakukan hanya sampai pada langkah 2 dengan ujicoba terbatas dan belum melakukan ujicoba produk melalui eksperimen dan sosialisasi produk. Langkah-langkah penelitian tersebut dapat divisualisasikan seperti gambar 1 .

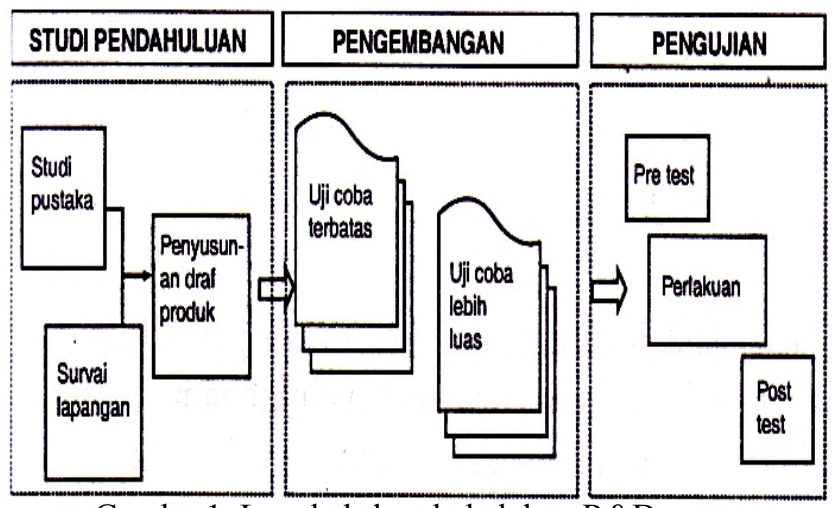

Gambar1. Langkah-langkah dalam R\&D

Pemilihan pokok bahasan dalam penelitian adalah bebas asalkan yang berhubungan dengan fisika dan aplikasinya, sedangkan ujicoba terbatas diterapkan pada mahasiswa Jurusan Fisika Unesa yang berjumlah 50 orang yang sedang memprogram mata kuliah multimedia. Pemilihan jurusan semata-mata didasarkan pada kemudahan akses yang dimiliki penulis sehingga sangat mendukung keberhasilan penelitian. Langkah-langkah penelitian yang telah dilakukan terinci sebagai berikut:

1. Studi pendahuluan yang meliputi: pengkajian tentang media pembelajaran, pengkajian tentang karakteristik mahasiswa fisika, pengkajian tentang hasil penelitian terdahulu yang relevan, pengkajian karakteristik facebook, dan pengkajian karakteristik fisika, serta membuat rencana pembelajarannya,

2. Selanjutnya (masih bagian studi pendahuluan) mengembangkan pembelajaran melalui facebook untuk melatihkan keterampilan berpikir kritis mahasiswa yang didukung dengan gambar dan video yang relevan dengan materi pembelajaran. Langkah pengembangan pembelajaran melalui facebook yang melatihkan keterampilan berpikir kritis adalah sbb:

a. Membuat akun di facebook dan membuat profil dosen kemudian membuat grup komunitas. Selanjutnya memerintahkan masing-masing mahasiswa agar memiliki akun dan profil di facebook dan menjadi anggota komunitas di grup tersebut. Untuk melacak pemilik profil (karena biasanya menggunakan nama samaran), mahasiswa diminta melaporkan akun dan profilnya masing-masing melalui pesan di dinding dosen.

b. Untuk melatih keterampilan berpikir kritis mahasiswa yang meliputi: menganalisis, mensintesis, menilai, menerapkan, membangkitkan gagasan, mengekspresikan gagasan, dan memecahkan masalah, semua mahasiswa diminta mengunggah setidaknya satu gambar, satu video, dan membuat tautan satu video yang berhubungan dengan fenomena atau aplikasi fisika melalui grup komunitas. Selanjutnya masing-masing gambar dan video yang diunggah, dan video yang ditautkan harus diberi penjelasan berkaitan dengan substansi fenomena atau aplikasi fisika oleh mahasiswa yang mengunggah atau menautkan tersebut.

c. Keterampilan berpikir kritis mahasiswa juga dilatihkan dengan cara memberikan kesempatan kepada masing-masing mahasiswa untuk memberikan komentar, mengkritisi, memperluas dan memperkaya penjelasan gambar dan video yang diunggah dan ditautkan oleh teman lain sesama anggota komunitas dalam grup.

3. Pengembangan yang meliputi: mempersiapkan lembar telaah untuk tim dosen, angket respon mahasiswa terhadap dampak pelaksanaan pembelajaran melalui facebook yang melatihkan keterampilan berpikir kritis, dan melakukan ujicoba terbatas. Keterampilan berpikir kritis mahasiswa yang tercermin dari penjelasan dan komentar masing- masing mahasiswa tersebut selanjutnya ditelaah oleh tim dosen untuk dinilai apakah keterampilan berpikir mahasiswa dalam kategori baik atau kurang. Di samping itu, juga dibagikan angket kepada mahasiswa untuk mengetahui dampak pelaksanaan pembelajaran melalui facebook terhadap keterampilan berpikir kritis.

Analisis data yang digunakan dalam penelitian ini adalah statistik deskriptif Data yang bersifat kuantitatif diolah dengan statistik yang sesuai, sedangkan data yang bersifat kualitatif diolah secara deskriptif. 


\section{HASIL PENELITIAN DAN PEMBAHASAN}

Langkah awal pembelajaran adalah membuat akun di facebook dan profil dosen yang diberi nama "Rudy Unesa", kemudian membuat grup komunitas yang diberi nama "Komunitas Media Fisika". Selanjutnya memerintahkan masing-masing mahasiswa agar memiliki akun dan profil di facebook dan menjadi anggota komunitas di grup tersebut. Untuk melacak pemilik profil mahasiswa diminta melaporkan akun dan profilnya masing-masing melalui pesan di dinding dosen. Grup "Komunitas Media Fisika" tersebut mempunyai tampilan seperti Gambar 2.

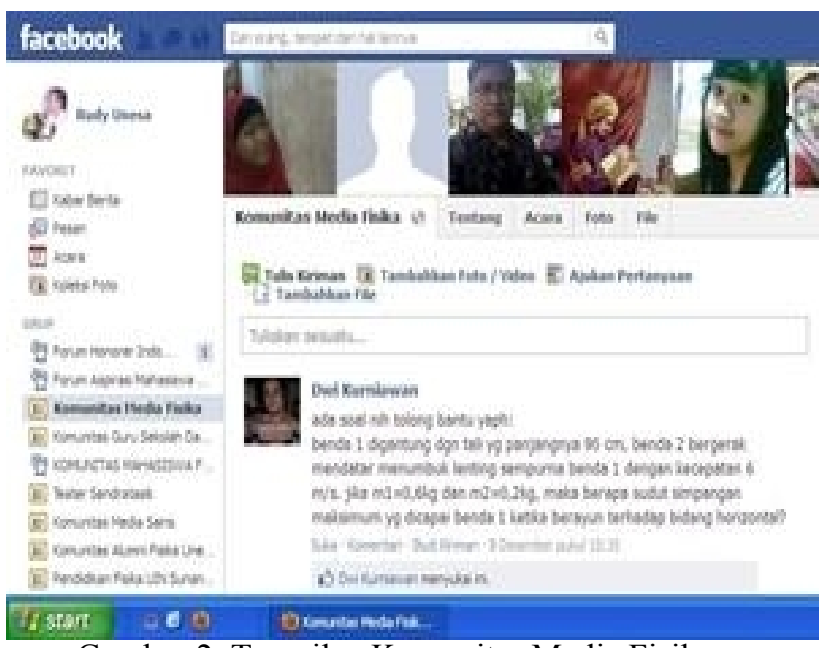

Gambar 2. Tampilan Komunitas Media Fisika

Untuk melatih keterampilan berpikir kritis mahasiswa yang meliputi: menganalisis, mensintesis, menilai, menerapkan, membangkitkan gagasan, mengekspresikan gagasan, dan memecahkan masalah, semua mahasiswa diminta mengunggah setidaknya satu gambar, satu video, dan membuat tautan satu video yang berhubungan dengan fenomena atau aplikasi fisika melalui grup komunitas. Selanjutnya masing-masing gambar dan video yang diunggah, dan video yang ditautkan harus diberi penjelasan oleh mahasiswa yang mengunggah atau menautkan tersebut. Contoh gambar dan video yang diunggah mahasiswa, serta video yang di tautkan beserta penjelasannya adalah seperti Gambar 3.

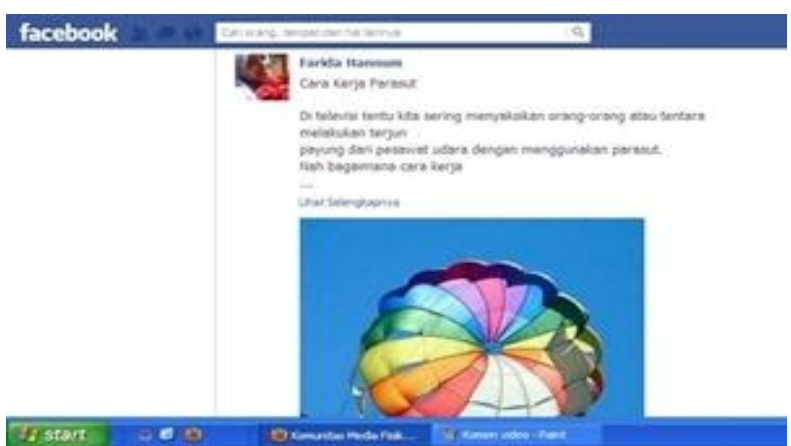

Gambar 3a. Contoh gambar yang diunggah beserta penjelasannya

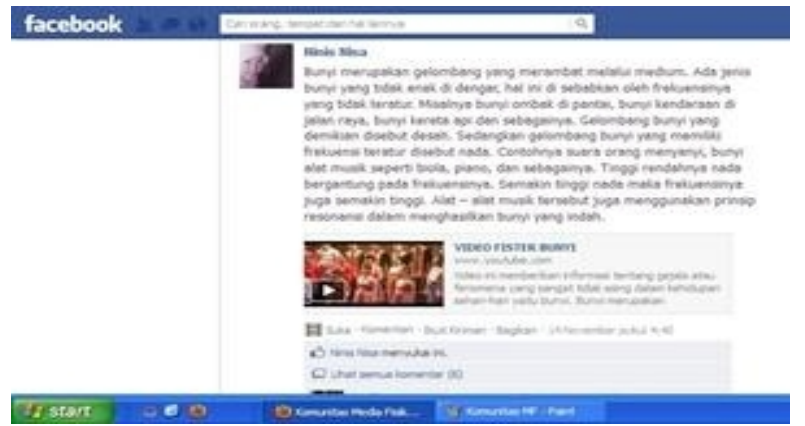

Gambar 3b. Contoh video yang diunggah beserta penjelasannya

Keterampilan berpikir kritis mahasiswa juga dilatihkan dengan cara memberikan kesempatan kepada masing-masing mahasiswa untuk memberikan komentar, mengkritisi, memperluas dan memperkaya penjelasan gambar dan video yang diunggah dan di tautkan oleh teman lain sesama anggota komunitas dalam grup. Contoh komentar gambar dan video yang diunggah mahasiswa lain, serta video yang di tautkan adalah seperti Gambar 4.

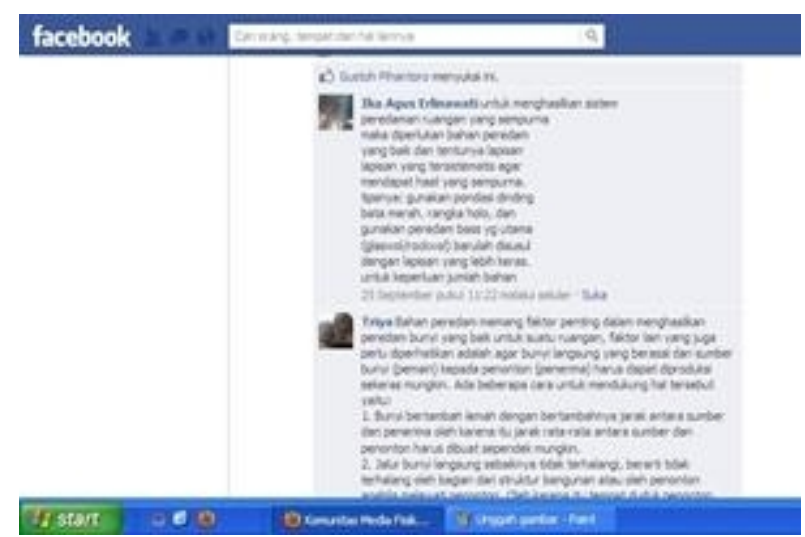

Gambar 4a. Contoh komentar gambar yang diunggah

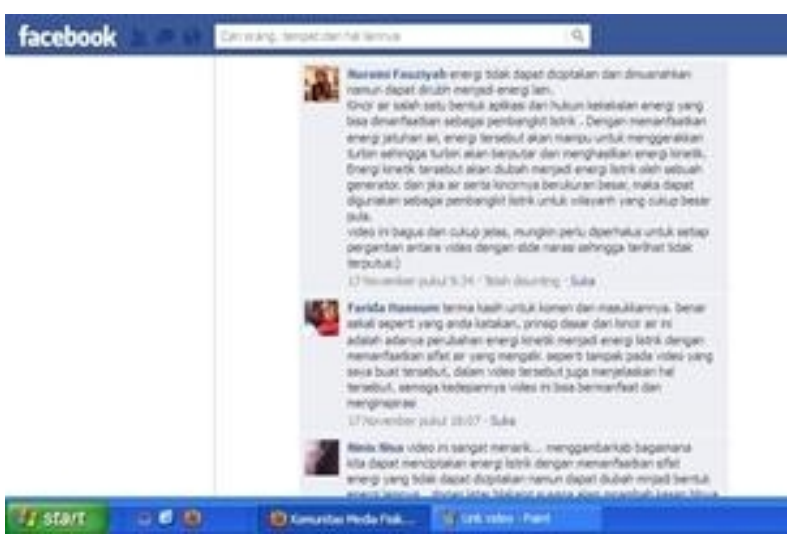

Gambar 4b. Contoh komentar video yang ditautkan

Keterampilan berpikir kritis mahasiswa yang tercermin dari penjelasan dan komentar masing-masing mahasiswa tersebut selanjutnya ditelaah oleh tim dosen untuk dinilai apakah keterampilan berpikir kritis mahasiswa dalam kategori baik atau kurang. Di samping itu mahasiswa diberi angket untuk menilai dampak 
pembelajaran melalui facebook terhadap keterampilan berpikir kritis. Untuk memandu agar mahasiswa tidak mengalami kesulitas dalam menilai, dan tidak melalukan kesalahan akibat salah interpretasi tentang keterampilan berpikir kritis yang dimaksud, pada angket tersebut diberikan deskripsi tentang keterampilan berpikir kritis mengacu pada Tabel 1. Hasil penilaian dari dosen maupun mahasiswa selanjutnya direkapitulasi dan dihitung persentasinya berdasarkan kriteria penilaian baik dan kurang. Hasil penilaian dosen dan penilaian mahasiswa tentang dampak pembelajaran melalui facebook terhadap keterampilan berpikir kritis tersebut adalah seperti Tabel 2.

Tabel 2. Dampak pembelajaran melalui facebook terhadap keterampilan berpikir kritis

\begin{tabular}{|l|l|c|c|c|c|}
\hline \multirow{2}{*}{ No } & \multirow{2}{*}{ Keterampilan } & \multicolumn{2}{|c|}{$\begin{array}{c}\text { Penilaian } \\
\text { Dosen }\end{array}$} & \multicolumn{2}{c|}{$\begin{array}{c}\text { Penilaian } \\
\text { Mahasiswa }\end{array}$} \\
\cline { 3 - 6 } & $\begin{array}{c}\text { Baik } \\
\mathbf{( \% )}\end{array}$ & $\begin{array}{c}\text { Kurang } \\
(\%)\end{array}$ & $\begin{array}{c}\text { Baik } \\
\mathbf{( \% )}\end{array}$ & $\begin{array}{c}\text { Kurang } \\
(\%)\end{array}$ \\
\hline 1 & $\begin{array}{l}\text { Menganalisis } \\
\text { (Analyzing) }\end{array}$ & 80 & 20 & 88 & 12 \\
\hline 2 & $\begin{array}{l}\text { Mensitesis } \\
\text { (Synthesizing) }\end{array}$ & 70 & 30 & 74 & 26 \\
\hline 3 & $\begin{array}{l}\text { Menilai } \\
\text { (Evaluating) }\end{array}$ & 75 & 15 & 86 & 14 \\
\hline 4 & $\begin{array}{l}\text { Menerapkan } \\
\text { (Applying) }\end{array}$ & 90 & 10 & 98 & 2 \\
\hline 5 & $\begin{array}{l}\text { Membangkitkan } \\
\text { Gagasan }\end{array}$ & 85 & 15 & 90 & 10 \\
\hline 6 & $\begin{array}{l}\text { Mengekspresikan } \\
\text { Gagasan }\end{array}$ & 80 & 20 & 86 & 14 \\
\hline 7 & $\begin{array}{l}\text { Memecahkan } \\
\text { masalah }\end{array}$ & 70 & 30 & 74 & 26 \\
\hline
\end{tabular}

Berdasarkan data diatas tampak bahwa penilaian dosen maupun mahasiswa sendiri mengarah pada penilaian yang baik (analyzing $\geq 80 \%$, synthesizing $\geq 70 \%$, evaluating $\geq 75 \%$, applying $\geq 90 \%$, generating ideas $\geq$ $85 \%$, expressing ideas $\geq 80 \%$, dan Solving Problems $\geq$ $62 \%$ ). Hal tersebut menunjukkan bahwa pembelajaran melalui facebook dapat digunakan untuk melatihkan keterampilan berpikir kritis mahasiswa.

Rasionalisasi hasil tersebut dapat dijelaskan sbb:

1. Menganalisis (Analyzing): Ketika mahasiswa memberi penjelasan tentang gambar dan video yang diunggah sendiri, dan ketika mengomentari penjelasan gambar dan video yang diunggah mahasiswa lain, maka mahasiswa yang bersangkutan harus mempelajari sesuatu untuk mengidentifikasi unsur-unsur atau hubungan antar unsur-unsur dari fenomena fisika yang terjadi.

2. Mensitesis (Synthesizing): Ketika mahasiswa memberi penjelasan tentang gambar dan video yang diunggah sendiri, dan ketika mengomentari penjelasan gambar dan video yang diunggah mahasiswa lain, maka mahasiswa yang bersangkutan harus menggunakan penalaran deduktif untuk menarik serentak unsur-unsur kunci dari fenomena fisika yang terjadi.

3. Menilai (Evaluating): Ketika mahasiswa mengomentari penjelasan gambar dan video yang diunggah mahasiswa lain, maka mahasiswa yang bersangkutan harus meninjau dan menanggapi secara kritis gagasan yang disajikan, dan menilainya berdasarkan tujuan, standar, atau kriteria tertentu.

4. Menerapkan (Applying): Ketika mahasiswa akan mengunggah gambar dan video serta memberikan penjelasan tentangnya, maka mahasiswa yang bersangkutan harus menggunakan gagasan-gagasan, proses, atau keterampilan terkait fenomena fisika dan aplikasinya dalam situasi yang baru.

5. Membangkitkan Gagasan (Generating Ideas): Ketika mahasiswa memberi penjelasan tentang gambar dan video yang diunggah sendiri, dan ketika mengomentari penjelasan gambar dan video yang diunggah mahasiswa lain, maka mahasiswa yang bersangkutan harus mengerahkan segala kemampuan untuk mengekspresikan pikiran yang mengungkapkan orisinalitas, spekulasi, imajinasi, sebuah perspektif pribadi, fleksibilitas dalam berpikir, penemuan atau kreativitas terkait fenomena fisika dan aplikasinya.

6. Mengekspresikan Gagasan (Expressing Ideas): Ketika mahasiswa akan mengunggah gambar dan video serta memberikan penjelasan tentangnya, maka mahasiswa yang bersangkutan harus menyajikan gagasan awal dan logis sambil menggunakan bahasa yang mudah dipahami oleh audien.

7. Memecahkan masalah (Solving Problems): Ketika mahasiswa akan mengomentari penjelasan gambar dan video yang diunggah mahasiswa lain, sementara komentar-komentar dari mahasiswa lain juga sudah tersajikan, maka mahasiswa yang bersangkutan harus menggunakan keterampilan berpikir kritis untuk menemukan pemecahan masalah akibat terjadinya silang pendapat antar mahasiswa yang memberikan komentar pada satu fenomena/aplikasi fisika yang sama.

Berdasarkan hasil penelitian tersebut di atas, maka pembelajaran melalui facebook dapat menjadi satu alternatif pembelajaran efektif yang menggunakan teknologi informasi dan komunikasi (TIK), karena berdampak terhadap keterampilan berpikir kritis mahasiswa. Di samping itu, pembelajarn melalui facebook juga dapat digunakan sebagai pendorong agar tren penggunaan facebook khususnya oleh kalangan pelajar dan mahasiswa dapat diberdayakan untuk penggunaan yang lebih bermanfaat. 


\section{SIMPULAN}

Pembelajaran melalui facebook yang dapat melatihkan keterampilan berpikir kritis mahasiswa dapat dibuat dengan membuat grup komunitas. Untuk melatih keterampilan proses sains mahasiswa diminta mengunggah setidaknya satu gambar, satu video, dan membuat tautan satu video yang berhubungan dengan fenomena atau aplikasi fisika beserta penjelasannya melalui grup komunitas. Keterampilan berpikir kritis mahasiswa juga dilatihkan dengan cara memberikan kesempatan kepada masing-masing mahasiswa untuk memberikan komentar, mengkritisi, memperluas dan memperkaya penjelasan gambar dan video yang diunggah dan ditautkan oleh teman lain sesama anggota komunitas dalam grup.

Berdasarkan penilaian dosen maupun mahasiswa sendiri menunjukkan bahwa pembelajaran melalui facebook berdampak positif terhadap keterampilan berpikir karena hasil penilaian menunjukkan hasil yang baik (analyzing $\geq$ $80 \%$, synthesizing $\geq 70 \%$, evaluating $\geq 75 \%$, applying $\geq$ $90 \%$, generating ideas $\geq 85 \%$, expressing ideas $\geq 80 \%$, dan Solving Problems $\geq 62 \%$ ). Hal tersebut menunjukkan bahwa pembelajaran melalui facebook dapat digunakan untuk melatihkan keterampilan berpikir kritis mahasiswa.

Berdasarkan hasil penelitian tersebut, maka pembelajaran melalui facebook dapat menjadi satu alternatif pembelajaran efektif yang menggunakan teknologi informasi dan komunikasi (TIK), karena berdampak signifikan terhadap keterampilan berpikir kritis mahasiswa. Di samping itu, pembelajarn melalui facebook juga dapat digunakan sebagai pendorong agar tren penggunaan facebook khususnya oleh kalangan pelajar dan mahasiswa dapat diberdayakan untuk penggunaan yang lebih bermanfaat.

\section{DAFTAR PUSTAKA}

De Vito, Alfred. 1989. Creative Wellsprings for Science Teaching. West Lafayette, Indiana: Creative Venture. Feynman R., 2010, Basic Physics, The Feynman Lectures on Physics Volume 1 Chapter 02.

Hartono, B., (2004), Pemanfaatan TIK dalam Pembelajaran. Tersedia pada Error! Hyperlink reference not valid.. Diakses pada tanggal 10 Desember 2012.

Kustijono, R, 2012, Pembelajaran melalui Facebook Yang Melatihkan Keterampilan Proses Sains Dasar Dalam Mata Kuliah Media Pembelajaran, Seminar Nasional Pendidikan Sains Ke IV, Universitas negeri Surabaya, 15 Desember 2012.

Ruiz M.A., Primo, 2009, Towards a Framework for Assessing 21st Century Science Skills, Commissioned paper for The National Academies, University of Colorado Denver,February, 2009

Sadiman, Arif, 2007, Media Pendidikan, pengertian,
Pengembangan, dan Pemanfaatannya. PT Raja Grafindo Persada. Jakarta.

Sukmadinata, 2012, Metode Penelitian Pendidikan, Remaja Rosdakarya, Bandung.

Trilling, B. dan Hood, P. 1999. Learning, Technology, and Education Reform in the Knowledge Age or "We're Wired, Webbed, and Windowed, Now What"? Educational Technology may-June 1999.

Valentino, Catherine, 2000, Developing Science Skills, Houghton Mifflin Company. 